\title{
Radicalization and attenuation in the construction of tourism employment images: a multi-level frame analysis
}

\author{
Andreas Mölk \\ Division for Management in Health and Sport Tourism, \\ Private University of Health Sciences Medical Informatics and Technology, \\ Hall, Austria \\ Manfred Auer \\ Department of Organisation and Learning, University of Innsbruck, \\ Innsbruck, Austria, and \\ Mike Peters \\ Department of Strategic Management Marketing and Tourism, \\ University of Innsbruck, Innsbruck, Austria
}

\begin{abstract}
Purpose - Tourism employment is very diverse ranging from precarious, exploitative study to high-quality workplaces. However, poor employment images dominate the tourism industry, which makes attracting employees difficult. This study aims to examine the processes that lead to such image construction.

Design/methodology/approach - Using a qualitative methodology, the study develops a multilevel framing cycle comprising a media analysis of newspapers and magazines (macro-level), a conversation analysis of peer communication/negotiations (meso-level) and a content analysis of single employee/ manager interviews (micro-level); and a comparative analysis of the macro-, meso- and micro-level findings.

Findings - The multilevel frame cycle identifies image-construction processes that pass through working conditions, payment, seasonality and human resource problems. These processes are shaped by the two cross-level dynamics of radicalization and attenuation. The latter consists of rationalized and repressed framings of tourism employment images (TEI) and the former consists of ideological and emotional framings.
\end{abstract}

(C) Andreas Mölk, Manfred Auer and Mike Peters. Published by Emerald Publishing Limited. This is published under the Creative Commons Attribution (CC BY 4.0) licence. Anyone may reproduce, distribute, translate and create derivative works of this article (for both commercial and noncommercial purposes), subject to full attribution to the original publication and authors. The full terms of this licence may be seen at http://creativecommons.org/licences/by/4.0/legalcode

The research presented in this article is part of the research project EBKOM, which is funded by the Tyrolian State Government's Translational Research Programme. However, the funder did not play a role in the study design; collecting, analysing, and interpreting the data; writing the report; and the decision to submit the article for publication.

They thank all members of the EBKOM research group for their helpful support in the development of this paper.

The University of Innsbruck funded the open access publication of this article. 
$\mathrm{IJCHM}$

34,2

Practical implications - Tourism stakeholders should support and participate in a pragmatic and open dialog to overcome the radicalization and attenuation of tourism employment. The key players require a new deal to end the "information warfare" on tourism employment, inaugurating a new era of collaborative and constructive employment relations.

Originality/value - This study develops a holistic and dynamic understanding of TEI by exploring how media products, peer groups and employees/managers jointly construct these images. It demonstrates how attenuation and radicalization shape poor employment images in tourism. It argues that these dynamics "lock in" the status-quo, create mutual recrimination between employers and employees and counteract common strategies that could otherwise improve employment structures and the image of tourism.

Keywords Cross-level dynamic, Employment image, Frame analysis, Radicalization, Attenuation

Paper type Research paper

\section{Introduction}

Research on employment images is important for the tourism and hospitality industries, which often struggle with labor shortages (Fes, 2018) and problems attracting a qualified workforce (Baum, 2019b; Daniel et al., 2017). Poor employment work images are a major cause of those difficulties, as tourism employment is often associated with unacceptable and demanding conditions (Baum, 2018) and precarious employment structures (Robinson et al., 2019). However, tourism employment is diverse in terms of both workplace quality and work experiences (Baum, 2019a, 2018). Companies and entire regions have been striving to change poor employer and work images and highlight the positive aspects of tourism employment. These efforts range from employer branding (Gehrels, 2019) to sustainable human resource (HR) strategies (Baum, 2018). Despite these efforts, negative images of tourism employment persist.

The literature on tourism employment images (TEI) does not fully explain this situation because it typically measures (potential) employee perceptions of aspects of tourism employment (McGinley et al., 2018; Schneider and Treisch, 2019; Wan et al., 2014). Two interlinked considerations are underdeveloped in this research as follows:

(1) The multilevel nature of TEI, including the role of nonemployee stakeholders (e.g. managers), social encounters (e.g. peer conversations) and institutional influences (e.g. media organizations).

(2) The processual, dynamic character of TEI.

Focusing on the interplay between the individual, interactional and institutional levels can help explain why the negative facets of tourism employment prevail. Research needs to go beyond analyzing the effects of issues, such as payment levels, career opportunities, work schedules and (potential) employee evaluations of job attributes by focusing on the processes and dynamics in the construction of TEI across multiple levels. Therefore, we ask as follows:

Q1. How are TEI constructed within and across individual, interactional and institutional levels?

To answer this question, we adopt Cornelissen and Werner's (2014) framework, which sensitizes framing within and across the macro- (institutional), meso- (interactional) and micro- (individual) levels. We then investigate the framing processes and dynamics in the construction of TEI, using media products, peer conversations and interviews to empirically examine the joint construction of TEI in Tyrol (Austria). Tyrol presents an excellent case for our purposes given the economic and sociocultural importance of tourism there, the problematic nature of TEI, the many initiatives taken to improve 
workplace quality and the image of tourism work in the region. We first discuss institutional, interactive and individual image construction processes as they relate to four overarching themes. Then, we discuss the cross-level dynamics that shape these processes, which are pivotal for the construction of TEI within and across different levels. This study introduces a holistic and dynamic understanding of TEI as the first multilevel frame analysis performed within this context.

\section{Literature review}

\subsection{Tourism employment: the ambiguity of working practices}

Employment in tourism and hospitality is diverse and it is difficult to generalize about working conditions, job attributes and quality (Baum, 2019a). Much of the literature emphasizes the negative facets of tourism employment, identifying poor and demanding working conditions (Armstrong, 2017), low pay (Baum et al., 2020), limited career opportunities (Goh and Okumus, 2020), stress and burnout related to emotional labor (Lee and Madera, 2019) and precarious employment structures (Baum, 2019a; Robinson et al., 2019). These studies highlight seasonality, contingent and nonstandard work forms and the utilization of cheaper worker cohorts, such as youth, women and migrant workers. Large parts of the workforce in tourism and hospitality experience job insecurity, exploitation and high levels of vulnerability (Baum et al., 2020; Robinson et al., 2019). However, the literature also describes the positive facets of tourism employment (Baum, 2019a; McPhail et al., 2015; Mooney et al., 2016), characterizing it as satisfying and fulfilling (Goh and Baum, 2021). It also explains how "employers of choice" (Baum et al., 2020, 2018) attempt to overcome the problems of tourism work and provide a set of progressive HR management policies.

\subsection{Tourism employment images: management of workforce perceptions}

The TEI literature reflects the ambiguity of work and employment in tourism. It is largely based on the paradigm of effective HR management and thus attempts to identify the factors influencing (potential) employee perceptions of working in the tourism and hospitality industries (Kusluvan and Kusluvan, 2000; Kusluvan et al., 2010). Many studies have measured the impact of general management, HR or marketing practices, such as sustainable business practices (Baum, 2018; Murray and Ayoun, 2010), relationship marketing (Cameron et al., 2009) and career opportunities (Richardson, 2009) and satisfaction (Chang and Busser, 2020) on potential and/or existing employees' perceptions of tourism employers. One stream of research has dealt with worker perceptions of the nature and social status of their work, including low pay and seasonality in tourism and hospitality (Wan et al., 2014) and the role of organizational status on TEI and employee attraction (McGinley et al., 2018). Scholars have elaborated on the problematic aspects of tourism employment, such as work-life conflicts, workplace-induced isolation (McGinley et al., 2017) and bad management behavior (Hight et al., 2019). Another stream of research has examined the role of student and/or employee characteristics in TEI perceptions, including their generational behavioral peculiarities (Goh and Lee, 2018; Richardson, 2010; Solnet and Hood, 2008; Tsaur and Yen, 2018; Zopiatis et al., 2012), the importance they place on their careers (Brown et al., 2014), their attitudes at work (Kusluvan, 2003; Zopiatis, 2007), the evaluative repertoires used to assess job attributes (Schneider and Treisch, 2019) and their cultural backgrounds and social networks (Janta et al., 2012).

\subsection{Considerations in tourism employment images research}

Despite the sophisticated ways in which scholars have studied TEI, two considerations remain underdeveloped. First, these studies have mainly focused on the individual level, usually investigating (potential) employees' perceptions of specific features of tourism 
IJCHM

34,2

employment. They have only minimally dealt with the interpretations of other individuals (e.g. managers, customers) and institutional stakeholders (e.g. media organizations and trade unions). Moreover, with the exception of Schneider and Treisch (2019), studies have not addressed social, cultural or institutional factors, including interactions within groups of employees or managers. Therefore, we conducted a multilevel analysis to overcome this onesided perspective, focusing on the impact of individual, interactional and institutional levels.

Second, aside from Goh and Lee (2018) and Hight et al. (2019), scholars have followed a functionalist and/or positivist epistemological orientation focused on measuring the impact of the factors influencing perceptions of employment images. They have largely neglected the processual and dynamic characteristics of TEI. Thus, we use a frame analysis approach common in general management (Ansari et al., 2013; Cornelissen et al., 2014) and tourism (Leung et al., 2019) research, which allows us to learn more about the emergence and consolidation of TEI.

\subsection{Levels and linkages in tourism employment images construction: a multilevel frame analysis}

We follow Cornelissen and Werner's (2014) agenda for a multilevel frame analysis to examine TEI construction. This agenda shifts the focus from a unilateral understanding toward "an enlarged conceptualization of framing" (215), which goes beyond a concern with single actors' involvement and the impacts of specific negative or positive facets of tourism employment and work.

This agenda organizes frame constructs into three levels. First, the micro-level outlines the sensemaking processes of single actors. In our research, the micro-level emphasizes tourism stakeholders' work experience, knowledge and attitudes. Second, the meso-level maps out meaning construction in groups. For our purposes, the meso-level sheds light on how work is processed among tourism peers. The macro-level describes the activation of "broader cultural templates of understanding" (Cornelissen and Werner, 2014, p. 182). In our study, the macro-level draws attention to widely accepted and recognized assumptions about working cultures or industry logic in tourism.

Cornelissen and Werner (2014) build three linkages between these levels to enable a multilevel frame analysis. First, the macro-micro linkage implies that the meaning constructions of single actors are "acts of framing in context" (215). Our study outlines how single stakeholders engage with working cultures and industry logic, such as the individual framing of job dissatisfaction in conjunction with precarious employment structures. Second, the micro-meso linkage indicates that frames are constructed via interaction and reveal participants' social identities. This linkage addresses, for example, the interactional framing of leadership behavior in tourism companies in relation to leader or follower identities. Third, the meso-macro linkage assumes that institutional frame constructs are built in a two-step manner as follows: first by establishing "personal common grounds" (217) during small-scale interactions between pairs of actors; and second through the emergence of "communal common grounds" (217) that spread across interactions, actors and time. This linkage outlines how institutionalized working cultures and industry logics, such as seasonality, are based on their framing within interactions.

\subsection{Framing cycles in tourism employment images construction: extending a multilevel frame analysis}

This study extends the suggestion of Cornelissen and Werner (2014) to link levels to pairs. We connect the macro-, meso- and micro-levels toward a framing cycle (Figure 1) to bring "ideas together in one location" (Entman, 1993, p. 51). We argue that frame analysis can also 


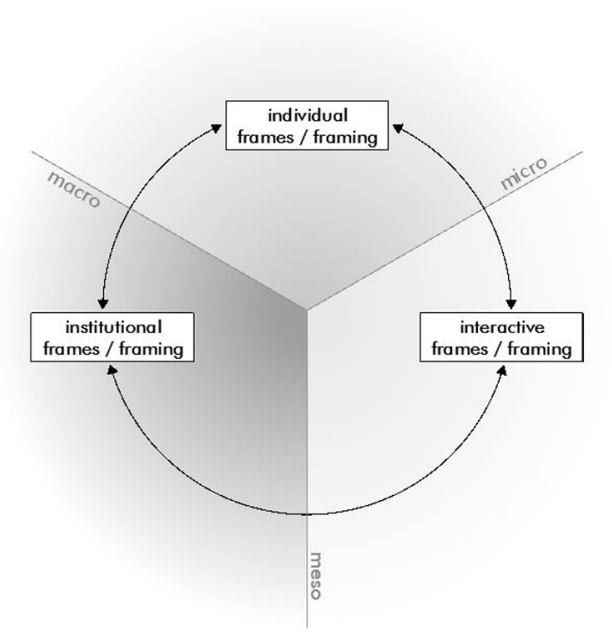

Multilevel
frame analysis

Source: (own illustration)

Figure 1.

Framing analysis cycle

be theorized as a circulating system in which all three levels are linked. We aim to link the institutional, interactional and individual framing of TEI. A framing cycle enables the analysis to elicit the cross-level dynamics and thrusts of meaning construction in tourism employment. By applying a framing cycle, we examine how the meanings of negative or positive facets of tourism employment and work spread across institutional, interactional and individual framing and establish employment images of tourism.

\section{Methods and research design}

\subsection{Contextual background of tourism employment images}

The Tyrolean tourism industry offers an exceptional opportunity to empirically investigate the construction of TEI. Tourism plays a major role in regional economies. According to the Tyrol Chamber of Labour (2020), the tourism industry employs $11 \%$ of the region's workforce. Moreover, the ambiguous character of tourism work and employment is especially pronounced in Tyrol. Critical employment reports highlight the negative facets of tourism employment and work (Biehl and Kaske, 2011). Likewise, many Tyrolean businesses enjoy employer-of-choice status among tourism students/interns. Moreover, due to a severe shortage of skilled and qualified labor (Austrian Hotelier Association, 2021), hotels and tourism associations have launched initiatives to improve the region's TEI (e.g. Job-Life-Achensee).

\subsection{Research design}

We used a qualitative research design for our multilevel frame analysis given the quantitative focus of most existing studies (Figure 2). An employment image is understood as an abstraction with socially, culturally and experientially constructed meanings. The qualitative research provides insights into the construction of employment images beyond the restrictions of statistical data. Importantly, existing frame analyses call for more rigorous qualitative research designs (Cornelissen and Werner, 2014) to capture the processes and dynamics of the framing. 


\section{IJCHM \\ 34,2}

\section{2}

Figure 2.

Research design

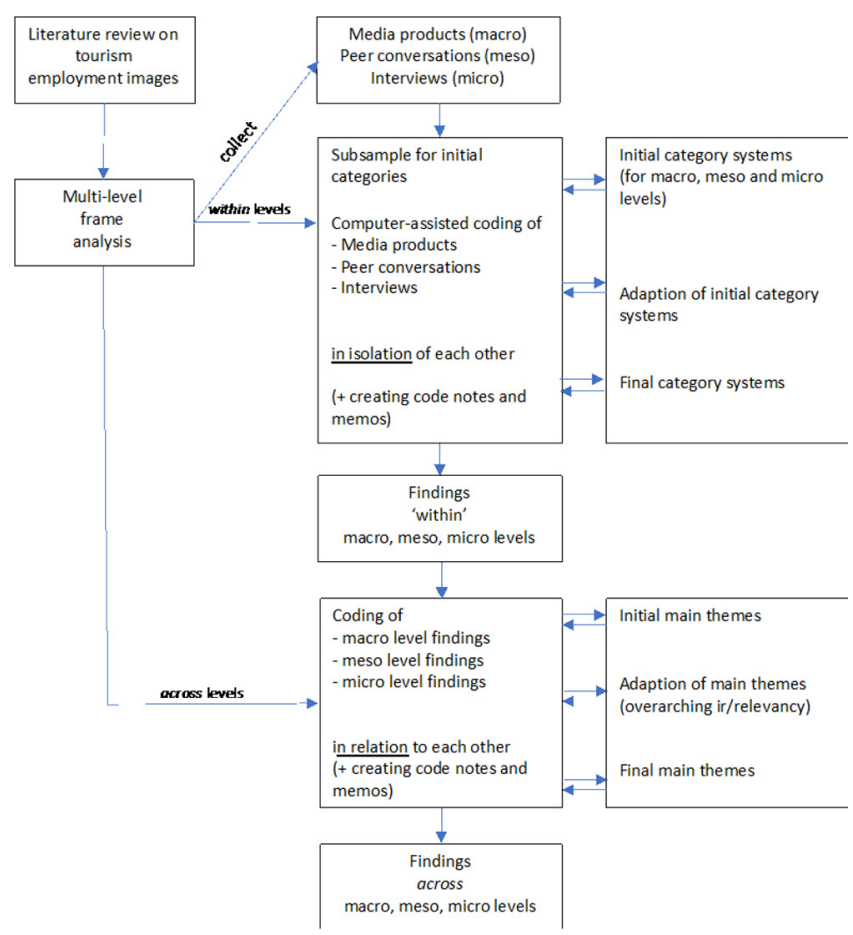

Source: (own illustration)

This study had two main objectives. First, it established a holistic understanding of TEI by performing three levels of analysis as follows: a macro-level to examine the institutional frames/framing of media organizations, a meso-level to examine the interactional frames/ framing of peer groups and a micro-level to examine the individual frames/framing of single employees/managers. These levels were established based on the TEI literature. Second, the study sought a dynamic understanding of TEI and linked the three levels to analyze the relationships between the institutional, interactional and individual frames/framing, following the proposal of a multilevel frame analysis in Cornelissen and Werner (2014) and our own notion of "framing cycle."

We investigated the macro-level through media organizations' reports on tourism work over time, the meso-level through peer communication/negotiations about work and the micro-level through single employees/managers work knowledge, experience and attitudes. Finally, the macro-meso-micro linkages were explored by examining the (overarching) themes in which media organizations, peer groups and employees/managers engaged while constructing the TEI.

\subsection{Data collection}

3.3.1 Macro-level. The first data set included media reporting over a period of approximately nine years (January 1, 2011, to December 31, 2019). The key inclusion criteria were as follows: The media coverage had to be important to the Tyrolean tourism industry; the target readership had to comprise potential or existing tourism employees/managers; and the 
coverage had to disseminate employment-relevant content. We included articles from the Tiroler Tageszeitung, the region's daily newspaper with the largest circulation in Tyrol (249 articles); Hotel and Touristik, a monthly hotel management magazine (56 articles); Tourist Austria International, published biweekly (135 articles); and Saison, a quarterly magazine for Tyrolean tourism managers (39 articles).

3.3.2 Meso-level. The second data set comprised 31 unstructured conversations conducted in 2015 during the so-called "Long Night of Research" with participants who were invited to discuss working in the Tyrolean tourism industry. The key inclusion criteria were that the participants required peer status and had to engage in conversations about tourism employment and peer-to-peer exchanges of employment knowledge and/or experiences. We observed 19 conversations among employees (ce1-19) and 12 conversations among managers or owners (cm1-12). The conversations varied in length (two to $16 \mathrm{~min}$ ) and group sizes (two to five peers). The conversations were audio recorded and transcribed.

3.3.3 Micro-level. The third data set included 36 semi-structured interviews with 18 employees (ie1-18) and 18 managers (im1-18). The key inclusion criteria were that the interviewees had to work in one of the traditional sub-sectors of the Tyrolean tourism industry

(e.g. hotel, restaurant) for at least three years or be in an active tourist employment relationship during the study period and had to describe themselves as either tourism employees or managers. Interviews were conducted between 2011 and 2019. The employees were between 21 and 37 years old and comprised both front-office (e.g. waitresses) and backoffice (e.g. chefs) staff. The managers were between 34 and 60 years old, including 13 top executives [e.g. chief executive officers (CEOs)] and five hotel owners. The choice of interviewees was random and depended on their willingness to participate. The interviews followed a storytelling approach (Czarniawska, 2004), with participants initially asked to "narrate" their work experience in the Tyrolean tourism industry. We also asked about career motives and opinions regarding past/current employers. The interviews took place in corporate offices or classrooms, averaged $44 \mathrm{~min}$ long and were audio recorded and transcribed.

\subsection{Data analysis}

A coding structure was established to process the media products, peer conversations and interviews at the beginning of our data analysis. We used MA codes for macro-level frames/ framing, ME codes for meso-level frames/framing and MI codes for micro-level frames/ framing. We built on these to create categories (e.g. ME1), sub-categories (e.g. ME1.1) and category systems for each of the three levels of analysis. To ensure validity, we used researcher triangulation (Mayring, 2014) in which all authors coded the three sets of data independently of one another. Different interpretations were discussed after the individual coding rounds and were incorporated into the analysis. To ensure effectiveness, we employed ATLAS.ti for interviews and conversations and Citavi for media products. Our data analysis [1] comprises two synchronized sequences (Figure 3).

3.4.1 First sequence. This sequence aimed at framing the media (macro-level), peer groups (meso-level) and individual employees/managers (micro-level). Here, we analyzed the three sets of data in isolation, exploring the construction of TEI "within" the levels (summarized in Table 1).

3.4.1.1 Media analysis. We examined media products at the macro-level following the principles of media analysis Altheide and Schneider (2013). First, we defined seven thematic units based on the TEI literature as follows: payment/compensation, work quality/ conditions, career advancement, labor shortages, the characteristics of potential employees, 


\section{$\mathrm{IJCHM}$ \\ 34,2}

\section{4}

Figure 3.

Data analysis (own illustration)

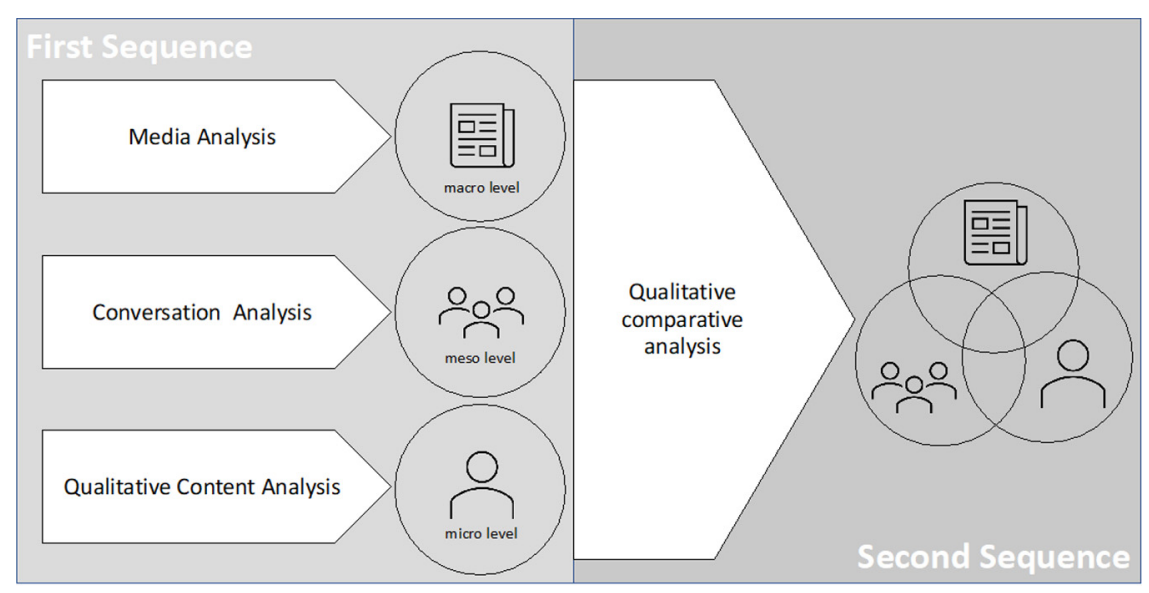

Source: (own illustration)

sustainable business practices and organizational/social status. Building on these, we derived keywords for each thematic unit. For instance, "working conditions" included the keywords "stress" and "working time." The media products were subsequently analyzed using a computer-assisted keyword search (APA-Defacto-Campus). The results for each theme were initially organized according to the year and place of publication. This resulted in 232 articles (an average of 58 per year), most coming from Tiroler Tageszeitung (121). Second, we processed the search results of each thematic unit to form categories (e.g. "MA4.2"). As this task produced 56 categories, we increased the level of abstraction via summarization and created main categories ("MA1" - "MA6"). Third, we evaluated the temporal aspects of our categories by studying how media coverage developed over time. We then created a final category system for the macro-level.

3.4.1.2 Conversation analysis. We used conversation analysis Sacks et al. (1974) as a framework to examine the peer conversations. First, we divided the conversation transcripts into episodes, focusing on those that provided information on turn-taking practices; forms (e.g. "struggling with the response"); and the frequency with which speaker turns were taken, maintained and yielded. We discovered no interactional TEI construction but observed an individual (manager/employee) construction in 13 peer conversations. Second, we separately analyzed the employee and manager episodes, inductively creating categories for the recurrent turn-taking practices of these two peer groups. We found that the turn-taking practices in the manager conversations were often comprising "refusing" or "highlighting" but were comprising "embracing" in the employee conversations. The turn-taking practices of "refining," "stressing," and "marginalizing" were evident in both peer groups. Third, we introduced a thematic focus and organized the categories according to TEI topics. This task resulted in six main categories ("ME1" - "ME6"). However, as these main categories were often very extensive, we structured them through the extraction (e.g. "ME1.2," "ME1.3"). This process resulted in a final category system for the meso-level.

3.4.1.3 Qualitative content analysis. At the micro-level, we examined all interview transcripts following qualitative content analysis principles (Mayring, 2014). We initially examined 10 transcripts line-by-line, five employee interviews (E) and five manager interviews (M). We formed categories (e.g. "MI 1.5") when there was a fit between interview excerpts and 
Level of

analysis

Macro-level
Category

(MA1) Emphasizing decrease in attraction and loyalty from (potential) employees (MA2) Embracing multifaceted nature of seasonal employment

(MA3) Addressing poor working conditions in tourism

(MA4) Highlighting political controversies about tourism salaries

(MA5) Portraying idealized and rational tourism careers

(MA6) Featuring labor market openings

Meso level
(ME1) Refusing employmentrelated difficulties

- (ME2) Highlighting beneficial aspects of tourism employment

- (ME3) Embracing problematic manager-employee relationships

- (ME4) Marginalizing seasonal aspects of tourism work

(ME5) Refining joint ideological payment positions

(ME6) Stressing the practical orientation of tourism work
Sub-category

Multilevel frame analysis

- (MA1.1) Labor shortage

- (MA1.2) Job dissatisfaction

- (MA1.3) High labor turnover

- (MA2.1) Boreout during low seasons

- (MA2.2) Burnout after high seasons

- (MA2.3) Approaches to year-round employment

- (MA2.4) Seasonal job rotation models

- (MA3.1) Long and unreasonable working hours

- (MA3.2) High physical demands

- (MA3.3) Psychological burdens

- (MA3.3) Negative consequences for tourism workforces

- (MA4.1) Employer representatives' defense of payment policies and practices

- (MA4.2) Union representatives' attack on payment policies and practices

- (MA5.1) Storybook/ideal-typical career paths

- (MA5.2) Educational career paths

- (MA6.1) Eastward expansion and foreign professionals

- (MA6.2) Changes in the local job markets

- (MA6.3) Indigenous issues: unattractive local labor market for local workers

- (ME1.1) Illness figures (M)

- (ME1.2) Employee dissatisfaction (M)

- (ME1.3) Professional shortages (M)

- (ME2.1) Work safety (M)

- (ME2.2) Employability of professionals (M)

- (ME2.3) Range of tasks (M)

- (ME2.4) The team element of tourism jobs (M)

- (ME3.1) Authoritarian leadership attitudes (E)

- (ME3.2) Social grievances (E)

- (ME3.3) Poor management behavior (E)

- (ME4.1) Avoidance of seasonality discussions (E, M)

- (ME4.2) Future seasonal job/workplace (E)

- (ME4.3) Off-seasonal vacation plans (E)

- (ME4.4) Recurring seasonal (key) events (M)

- (ME5.2) Radical advice (E, M)

- (ME5.3) "Friends and foes" schemata (E, M)

- (ME5.1) One-sided lines of argumentation (E, M)

- (ME6a) Difference between theoretical training and practical use $(\mathrm{M})$

(continued)

\section{5}

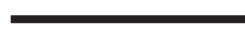


(MI1) Condemning bad tourism working conditions

(MI2) Distancing from apparent and potential criticism of poor tourism working conditions

(MI3) Downplaying problematic HR figures and facts

(MI4) Sustaining ideological views of tourism wages

(MI5) Approaching retrospective and prospective careers

(MI6) Marginalizing seasonality with content-related dimension

(MI7) Stressing the role of status of work in tourism (MI8) Portraying characteristics of (potential) employees
- (ME6b) Over-qualification of tourism experts (E, M)

- (ME6c) Future of tourism work (E, M)

- (MI1.1) Bad working atmosphere and climate (E)

- (MI1.2) (Considerable) rivalry among employees (E)

- (MI1.3) Poor communication practices (E)

- (MI1.4) Unfavorable working times and schedules (E)

- (MI1.5) Negative work experiences (E)

- (MI2.1) False/misleading media reports on working conditions (M)

-(MI2.2) Unchangeable nature of tourism work (M)

- (MI3.1) Increasing sickness figures (M)

- (MI3.2) Shortage of skilled workers (M)

- (MI3.3) Decreasing local workforce (M)

- (MI4.1) Personal experiences of financial exploitation (M, E)

- (MI4.2) High price pressure and industry competition (M)

- (MI5.1) Future career intentions: personal life planning and job ambitions (E)

- (MI5.2) Past career moves: personal achievements, significant work experiences and key milestones (M)

- (MI6.1) Immovable requirement of seasonality (E)

- (MI6.2) Taking seasonality for granted (M)

-(MI7.1) Organizational status

- (MI7.2) Social status

- (MI8.1) Generation

- (MI8.2) Importance of careers

- (MI8.3) Work attitudes

Table 1.

the study's seven literature-based thematic units ("Media Analysis" section above). After stabilizing the initial category system (e.g. when no new categories were found), we conducted a revision loop in which the categories and coding were intercoder-evaluated. Points of revision were then discussed and if necessary, considered in the respective category systems. Second, we grouped categories (e.g. "excessive working hours" and "challenging schedules" were transferred to "MI1.4"), thereby creating a category system that embraced empirical insights from both the manager and employee interviews. Next, we analyzed the remaining 26 transcripts in accordance with this merged category system, verifying whether the revised categories were relevant and consistent with the rest of the interviews and adapting them where necessary. This resulted in 17 main categories and 45 subcategories. We then grouped similar categories again and built main categories ("MI2" - "MI8") to establish the micro-level category system. 
3.4.2 Second sequence. In the second sequence, we determined how the framing of media, peer groups and individual employees/managers was reciprocally influenced, exploring the construction of TEI "across" different levels (summarized in Table 2).

3.4.2.1 Qualitative comparative analysis. First, we compared and positioned the individual, interactional and institutional framings vis-à-vis each other and searched for overarching themes. We examined all the category systems and identified the topics that played a role at the macro-, meso- and micro-levels. We based the TEI construction on the following four overarching themes (Figure 4):

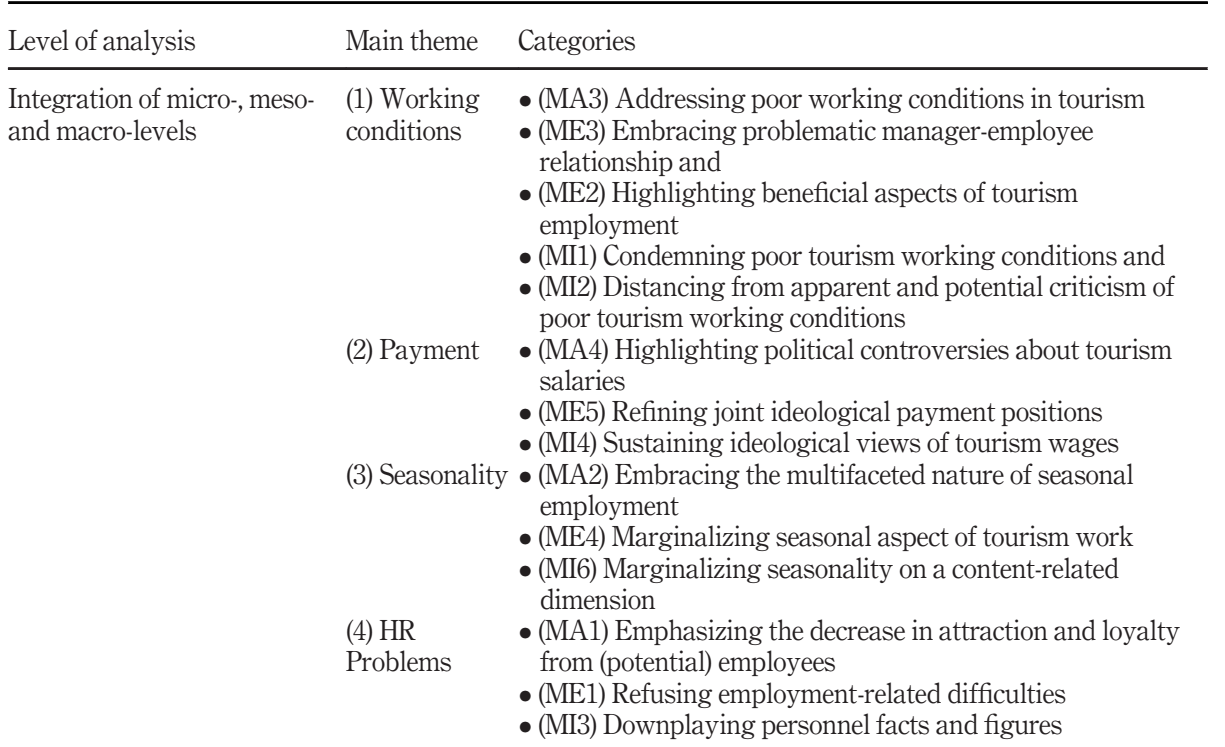

Table 2. Second sequenceconstruction of TEI "across" levels

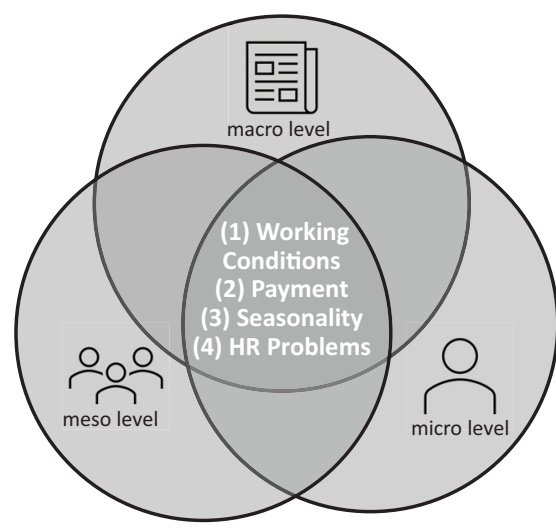

Source: (own illustration)
Figure 4 . Overarching themes in the construction of TEI 


$\begin{array}{ll}\text { IJCHM } & \text { (1) Working conditions. } \\ 34,2 & \text { (2) Payment. } \\ & \text { (3) Seasonality. } \\ & \text { (4) HR problems [2]. }\end{array}$

Second, we elaborated on the cross-level dynamics shaping the construction processes of these four themes. We began with the macro-level because we regarded media framing as an institutionalized, widely established discourse. We then explored how the meso- and microlevels within each theme were related to institutional framing. This procedure enabled us to determine that the "working conditions" and "payment" construction processes radicalized while "seasonality" and "HR problems" attenuated. Finally, we wrote a researcher's narrative consisting of topic-specific summaries.

The data analysis was continuously checked for reliability issues. In addition to the mutual checks performed by the authors, each analysis sequence was subjected to an inter-coder check (Mayring, 2014) that evaluated category systems and coding processes. The first sequence was evaluated by six masters' students (two at each level) and the second sequence was evaluated by a research fellow with knowledge of multilevel frame analysis. Points of concern (e.g. the demarcation of "working conditions") were discussed and where appropriated, incorporated in the respective data analysis areas.

\section{Findings and discussion}

\subsection{Working conditions}

4.1.1 Macro-level. The most prominent theme in the media products was working conditions. A total of 165 articles (34.4\% of all articles) addressed poor working conditions (MA3), including long and unreasonable working hours (MA3.1), high physical demands (MA3.2), psychological burdens (MA3.3) and negative consequences for workforces (MA3.4). The argumentation used was often emotionally charged due to the particularly critical discourse and had the potential to trigger an emotional escalation in readers. The latter can be seen in the following example:

These forms of generalization about "generally bad working conditions" are categorically rejected by hotelier Christoph P. from St. Anton. Black sheep can be found everywhere [. . .]. CEO Simone $Z$. from the DMO Tirol-West points out "clear improvements under these current framework conditions" It is not fair to continuously "pound on" the restaurant industry. (April 17, 2018, Tiroler Tageszeitung, p. 31)

4.1.2 Meso-level. Working conditions were also a key point of debate in employees' peer conversations. These stakeholders explicitly discussed the problematic manager-employee relationship (ME3). The employees had often confronted authoritarian leadership attitudes (ME3.1), social protests (ME3.2) or management misbehavior (ME3.3), which, in turn, often generated negative emotions (e.g. outrage and anger). This is exemplified in the following conversation, in which employees discuss recruitment material:

ce5: [overlap] but this doesn't match with reality/I know them.

ce4: $\mathrm{mmm}$ (.) okay (.) and

ce5: [overlap] I find things like that when there's a Hungarian worker named.

$<$ GABOR $>$ who works there gets a $<$ NAME TAG WITH HANS $>(0.2)$ these.

are things where I really think PERSONALLY this is not right (.) hiring.

foreign people and giving them other names so that the guests do not see where. 
they come from.

ce4: DAMN (.) by the NO MEANS OKAY. (.) INCREDIBLE.

Multilevel frame analysis

4.1.3 Micro-level. Negative press releases were highlighted in the employee interviews, with respondents mostly condemning poor working conditions (MI1). Employees reported a poor working atmosphere and environment (MI1.1), (considerable) rivalry among employees (MI1.2), poor communication practices (MI1.3) and unfavorable working hours and schedules (MI1.4). Poor tourism working conditions often upset the employees being interviewed, with interviewees reporting their own, often negative, work experiences (MI1.5). By contrast, managers distanced themselves from apparent and potential criticism about these issues (MI2). These stakeholders mostly criticized media reports on working conditions as being false or largely misleading (MI2.1). The managers also refuted potential criticism by asserting the unchangeable nature of tourism work (MI2.2; Table 3):

4.1.4 Meso-level. Interestingly, the managers largely ignored the apparent criticism in the peer discussions, instead highlighting the beneficial aspects of tourism employment (ME2). They mentioned work safety (ME2.1), the employability of professionals (ME2.2), the range of tasks (ME2.3) and the team element of tourism jobs (ME2.4). Discussing these beneficial aspects often triggered a positive emotional state (e.g. enthusiasm). The following excerpt offers an example:

cm10: from (your perspective) speaking (.) what motivates employees the most.

cm8: (0.5) difficult.

cm9: I think it has something to do with the team (.) that there is a great team.

cm8: I AGREE (.) but the host (.) The boss is also important.

cm10: $<$ so $>$ entire crew $()<$. ALL $>$

cm9: that's (.) all about.

From a multilevel framework perspective, the media laid the foundation for an emotional discourse on working conditions in tourism. The employers and employees both intensified

\begin{tabular}{ll}
\hline Categories & $\begin{array}{l}\text { Representative interview experts for working conditions } \\
\text { (Interviewee; sub-categories) }\end{array}$ \\
\hline MI1 & Employees: \\
& - "The way it (the working atmosphere) was - sometimes ... unbelievable ... - you \\
& can only shake your head (entirely uncomprehending) ... often tears followed when \\
& the cook made you feel like shit." (ie2; MI1.1) \\
& "The ORGANIZATION* does not consider working weekends to be a big deal at all." \\
& (ie14; MI1.4) \\
Managers: & "What you read about working in tourism (in the newspapers) is simply not true." \\
& (im11; MI2.1) \\
& "Working in a hotel, dealing with people on vacation, being in a good mood. ... Is \\
& there anything nicer? ... I can’t imagine a more fulfilling job!" (im13; MI2.2)
\end{tabular}

Note: *Anonymized

Table 3.

Working conditions 
IJCHM

34,2

this discourse by enriching and supporting the existing lines of argument (employees) or strongly contesting (employers and managers) the main characterization of working conditions in media coverage.

\subsection{Payment}

4.2.1 Macro-level. Payment also attracted extensive media attention (116 articles or $24.2 \%$ of the total). The reports highlight political controversies about tourism salaries (MA4). This became visible through the employer representatives' defense of payment policies and practices (MA4.1) on the one hand and union representatives' criticism of them on the other (MA4.2). For example, a featured story with an interview with a union representative refers to a survey on income in tourism, emphasizing the precarious situation for tourism employees:

Most employees are unsatisfied with the income situation, saying the union Vida [...] every second employee in tourism barely manages to pay for their basic needs. (Tiroler Tageszeitung, August 2, p. 20)

In another article, a representative of the largest association of hotel owners offered a generally positive view of developments concerning tourism salaries:

The average gross wages mostly increased in restaurant services, about 47 to 51 euros per employee. "This is more than a whole week's wages", said Thomas Reisenzahn, Secretary of the ÖHV (Austrian Hotel Association). (Tourism Austria International, October 7, 2011, p. 10)

The ideological distortions between employees and employers/managers about tourism wages became particularly obvious during negotiations on collective agreements. In this context, union representatives spoke of "modern slavery" (Tiroler Tageszeitung, August 17, 2012, p. 18), whereas employer representatives criticized union representatives for trying to "use the media politically" (Tiroler Tageszeitung, August 17, 2012, p. 18).

4.2.2 Meso-level. The peer discussions strongly confirmed the political controversies regarding tourism salaries. However, these discussions focused more on common grounds, as the managers and employees were both remarkably nuanced in their joint ideological payment positions (ME5), engaging in these conversations with radical advice (ME5.1), "friends and foes" schemata (ME5.2) and one-sided lines of argumentation (ME5.3). The following two conversations between employees and managers illustrate this:

ce12: you just don't make good money \{in a hotel\}.

ce13: mmm (.) okay (.) Do you think others \{employees\} say the same.

ce12: DEFINITELY $(0.3)>$ doubtless $<$

$\mathrm{cm} 1$ : the salary in our company is not that bad (0.2) NO serious complaints.

$\mathrm{cm} 2$ : treat people properly the salary is not the main aspect (.) ANYWAY.

(.) people forget the role of tips in tourism (.) that is the (main part) of.

their income.

4.2.3 Micro-level. The employees and employers maintained their ideological views on tourism wages (MI4). The individual framing was extremely rich in its detail and depth of focus, as the interviewees provided insight into how they arrived at their viewpoints. Both groups reported that these payment ideologies were based on personal experiences of financial exploitation (MI4.1). However, the managers emphasized the industry's heavy 
price pressure and competition (MI4.2) and the resulting impact on payment calculations (Table 4).

From a multilevel framing perspective, the media portrayed two diametrically opposed payment ideologies, which were recurrently supported and deepened in both interactive and individual framing.

\subsection{Radicalization}

The results show that the "working conditions" and "payment" framing saw additional momentum across levels, intensifying their impact on TEI. Both themes are characterized by the cross-level dynamic of "radicalization." We argue that radicalization becomes evident through emotionalism and/or ideologism (Figure 5).

Emotionalism implies an interpretation of the key indicators of effects, valence and arousal (Winkielman et al., 2007) and is most visible in the framing of working conditions.

\begin{tabular}{|c|c|}
\hline Categories & $\begin{array}{l}\text { Representative interview experts for payment } \\
\text { (Interviewee; sub-categories) }\end{array}$ \\
\hline MI4 & $\begin{array}{l}\text { Employees: } \\
\text { - "I have already worked in many restaurants, hotels, (mountain) huts ....... worked } \\
\text { for a long time (in these organizations) ... no matter where I worked, the owners are } \\
\text { all the same ....They don't care if you have enough (money) to live ..., they are all } \\
\text { profit-hungry and don't care much about their workers." (ie7; MI4.1) } \\
\text { Managers: } \\
\text { - "Dumping prices (on the internet) make it incredibly difficult for me to calculate cost- } \\
\text { covering ... this is of course also reflected in the salaries (of employees)." (im10; } \\
\text { MI4.2) } \\
\text { - "My hands are tied ... If I could, I would be the first to pay [all my employees] more } \\
\text {... but [nowadays] that just doesn't work." (im11; MI4.2) }\end{array}$ \\
\hline
\end{tabular}

Table 4. Payment

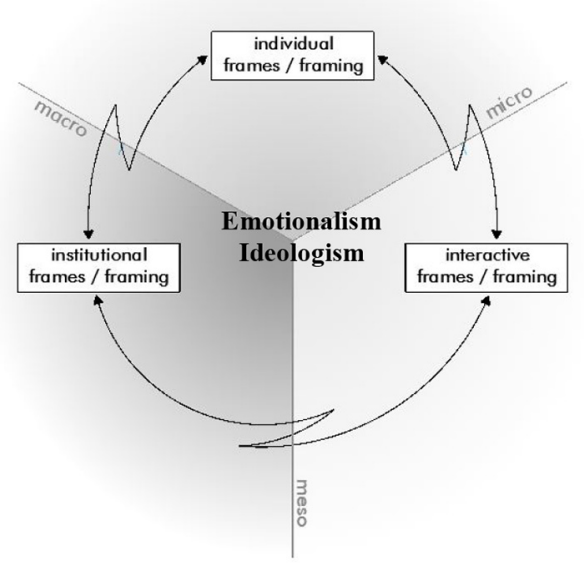

Source: (own illustration)

Figure 5. Radicalization 
IJCHM 34,2

The media laid the foundation for a critical engagement by "addressing bad working conditions in tourism." Employees then "condemned bad tourism working conditions," consequently defending the sentiment the media maintained in its reporting. Institutional frame constructs, therefore, influenced individual thinking (Benner and Tripsas, 2012). In our case, the media provide an emotional compass for the framing of tourism working conditions and employees sympathetically accept this institutional guidance. This compass constructs an essentially negative picture of tourism employment and ignores the meaningful and satisfying work experiences of tourism employees (Baum, 2019a; Mooney et al., 2016), the positive attitudes of hospitality students and their potential to become tourism employees (Goh and Lee, 2018) and the decent working conditions offered by "employers of choice" (Solnet et al., 2015). This one-sided framing of working conditions in tourism is problematic for the industry, as good working conditions and positive working experiences are critical for achieving attractive employment images, to a greater extent than extrinsic rewards (Wan et al., 2014).

Managers were "distancing from apparent and potential criticism of bad tourism working conditions," thus turning away from this emotional compass. They specifically pointed to incorrect interpretations/one-sided perspectives and focused on defending institutional work (Lefsrud and Meyer, 2012) by using three main strategies in their individual framing. First, managers "naturalized" and "romanticized" working conditions by relating them to their own "tough" work experiences, constructing specific features of work as either "normal" or/and "exciting." For them, being able to deal with these characteristics proved whether an employee had the right personality and attitude toward tourism work. Second, they assessed or included little of the critical media depictions of the tourism work environment, despite the empirical data proving its complexity and difficulty (Robinson et al., 2019). Third, managers connected their positive constructions of tourism employment to a framing of themselves as insiders while "defensively attacking" (Lefsrud and Meyer, 2012, p. 1479) critics as outsiders, who did not understand or fit the business, thus devaluing their criticism and constructing an emotionally charged "us vs. them" situation.

However, the data show a revaluation of emotionalism in the interactional framing of working conditions. This was clearly evidenced when manager groups/pairs "highlighted the beneficial aspects of tourism employment" while employees tended to "embrace problematic manager-employee relationships." With a focus on the latter, joint activities may also serve as a breeding ground in which the negative impressions or experiences of individuals can turn into negative emotional states for all participants. In fact, bad managerial behavior experienced by individual employees paved the way for collective aversion. Although negative management behavior is not uncommon in tourism (Baum, 2018), peer conversations may generate extreme leverage. Here, it appears easy to go from "problematic relationships" to "managers from hell" (Hight et al., 2019).

Ideologism implies an interpretation based on radical ideas/beliefs that have "considerable staying power" (Benford and Snow, 2000, p. 613) and are, thus resistant to criticism. Our findings illustrate ideologism most clearly through the framing of payments. As the media highlighted "political controversies about tourism salaries," union and employer representatives both disseminated featured stories "sustaining their own ideological views on tourism wages," which were either pro- or anti-employer. These stakeholders attempted to use the media in their "information warfare" to convince the wider public of the legitimacy and credibility of their stance on payment in tourism. In this context, the media are also "a vehicle for carrying and delivering the message to others" (Snow and Byrd, 2007, p. 132). Disseminated messages radicalize the discourse, signal a problematic situation, and thus aggravate the potentially 
negative impact of commonly used industrial payment policies, which are sometimes used to enhance the attractiveness of tourism employment (McGinley et al., 2017). However, the media are not just an institutional megaphone by which tourism stakeholders disseminate their ideologies. They may also capitalize on the potential of these ideologies, thus supplying a "strategic imperative" (Westby, 2004, p. 287) for the framing of tourism salaries.

Aside from media controversies, the inherent logic of ideologies aims to condemn the meaning systems of opponents (Oliver and Johnston, 2000). This was evidenced in our peer conversations, where managers and employees often "refined joint ideological payment positions" This ideologically charged atmosphere of tourism employment relations adds to the already negative reputation of pay in the industry (Ladkin, 2011; Wan et al., 2014). It hardly allows a more rational discourse on payment, such as discussions on the extent to which payment structures derive from the characteristics of the tourism industry or the (formal) level of employee qualifications and the kinds of jobs available (Casado-Díaz and Hipólito, 2016). The ideological discourse prevents the stakeholders from taking a constructive approach to criticism and hinders innovative solutions.

\subsection{Seasonality}

4.4.1 Macro-level. Seasonality was represented in the media through 44 articles $(9.2 \%)$, with broad temporal (covering all years) and spatial (across all newspapers and magazines) dissemination. This reporting highlighted the multifaceted nature of seasonal employment (MA2), with the media discussing so-called "boreout" during low seasons (MA2.1) and burnout following high seasons (MA2.2.), year-round employment approaches (MA2.3) and seasonal job rotation models (MA2.4). The following example illustrates the institutional framing in this context:

In fact, there are thousands of individual work crises that occur every winter, when the cable cars stand still and employees can no longer find jobs. (Tiroler Tageszeitung, May 2, 2012, p. 25)

4.4.2 Meso-level. Employees and managers both marginalized the seasonal aspect of tourism work in peer conversations (ME4). In fact, seasonality discussions were mostly avoided in their social encounters (ME4.1). In the best-case scenario, employees provided insights into future seasonal jobs and workplaces (ME4.2) or their off-season vacation plans (ME4.3). The latter is exemplified in the following dialog:

ce12: and where are you flying to in summer

ce13: uhhhh (.) good question (0.2) but I don't decide that

ce12: [laughing] (0.2), so this time I am flying to AUSTRALIA (.) for THREE months

The peer conversations among managers were similar. However, they did not focus on future seasonal jobs or off-season plans but rather on recurring seasonal (key) events (ME4.4), as the following discussion illustrates:

cm7: BOOOOM (0.2) suddenly IT was here.

cm4: IIIIIIT.

cm8: right after Christmas and New Year's Eve.

$\mathrm{cm} \overline{7}$ : EXACTLY.

$\mathrm{cm} 4$ : OOOOOK but that's nothing out of the ordinary.

$\mathrm{cm} 4$ : every year again. 
IJCHM

34,2

4.4.3 Micro-level. A similar framing of seasonality occurred in the interviews. However, the stakeholders spent more time discussing this issue, marginalizing seasonality within a content-related dimension as a result (MI6). The employees stated that seasonality is an unavoidable requirement in tourism work in Tyrol (MI6.1) and the managers likewise took seasonality for granted (MI6.2; Table 5).

A multilevel framing perspective shows how the strong media coverage of seasonality was marginalized in the peer conversations and interviews, either by questioning its impact or positing it as a self-evident component of tourism work. Both stakeholder groups argued in a highly rational manner and streamlined the issue into its basic elements. In doing so, they limited the role of seasonality in the construction of employment images in Tyrol.

\subsection{Human resource problems}

4.5.1 Macro-level. Reports on HR problems comprised 154 articles (32.2\%) and had broad temporal (covering all years) and spatial (covering all newspapers and magazines) dissemination. The media emphasized the decreased attraction and loyalty among (potential) employees (MA1), with articles discussing labor shortages (MA1.1), job dissatisfaction (MA1.2) and high labor turnover (MA1.3). The following excerpt provides an example:

The total number of seasonal workers has drastically decreased and the labor shortage in the industry has worsened. (Tiroler Tageszeitung, November 15, 2017, p. 21)

4.5.2 Meso-level. Unlike the media, the vast majority of managers refused to discuss employment-related difficulties with their peers (ME1). Furthermore, they attempted to avoid discussions of illness statistics (ME1.1), employee dissatisfaction (ME1.2) and professional shortages (ME1.3). The latter is illustrated by the following interaction:

cm5: what about employee turnover? turnover in your house?

$\mathrm{cm} 6$ : as in all other companies in tourism.

$\mathrm{cm} 5$ : can you be more precise (0.2) what was the turnover rate?

cm6: (0.5) wasn't that bad.

cm5: in numerical terms?

cm6: I have NO NUMERICAL TERMS in my head right now.

cm5: [overlap] okay okay.

Table 5.

Seasonality
Representative interview experts for seasonality

Categories (Interviewee; sub-categories)

MI6 Employees:

- "So, you know that right from the start when you choose the restaurant business ... you simply know that when you grow up here (in Tyrol), when you go to school here ... the season (seasonal work) is part of it (tourism employment), that's not a big deal." (ie11; MI6.1)

Managers:

- "Seasonal work is always 'cooked hotter than eaten', as we say ... it's the same every year ... after the winter, you keep hearing that it wasn't that bad after all.” (im3; MI6.2) 
4.5.3 Micro-level. The managers downplayed problematic HR figures and facts (MI3), being very hesitant to talk about increasing sickness figures (MI3.1), shortages of skilled workers (MI3.2) and the shrinking local workforce (MI3.3). Interestingly, these issues were framed during the interviews in far less detail than were working conditions or payments, although an interrelation between these topics is apparent. When managers were directly asked about HR problems, most responded as briefly and vaguely as possible, as exemplified in Table 6 .

From a multilevel framing perspective, the strong media coverage of HR problems was not reflected in the peer conversations and interviews. The employees completely ignored them and the managers largely refused to discuss them, leading to a partial repression of HR problems in the construction of TEI.

\subsection{Attenuation}

The framing of "seasonality" and "HR problems" can be characterized by the dynamic of attenuation, as it lost substance across the levels of analysis. We argue that attenuation is expressed by rationalization and/or repression (Figure 6).

Rationalization implies an interpretation along with abstract logics and/or formal standards. This is seen in the framing of seasonality, wherein employees and managers were marginalizing "seasonal aspects of tourism work" and "seasonality on a content-related dimension". Both

\begin{tabular}{|c|c|}
\hline Categories & $\begin{array}{l}\text { Representative interview experts for HR problems } \\
\text { (Interviewee; sub-categories) }\end{array}$ \\
\hline MI3 & $\begin{array}{l}\text { Managers: } \\
\text { - "I don't actually look at illness reports, only when they threaten me, our business .... But } \\
\text { so far it has always turned out well." (im15; MI3.1) } \\
\text { - "We get a not-inconsiderable share (of our workforce) from the east (Eastern Europe). ... } \\
\text { Hungary, Czech Republic, or the former East Germany." (im11; MI3.3) }\end{array}$ \\
\hline
\end{tabular}

Table 6. HR problems

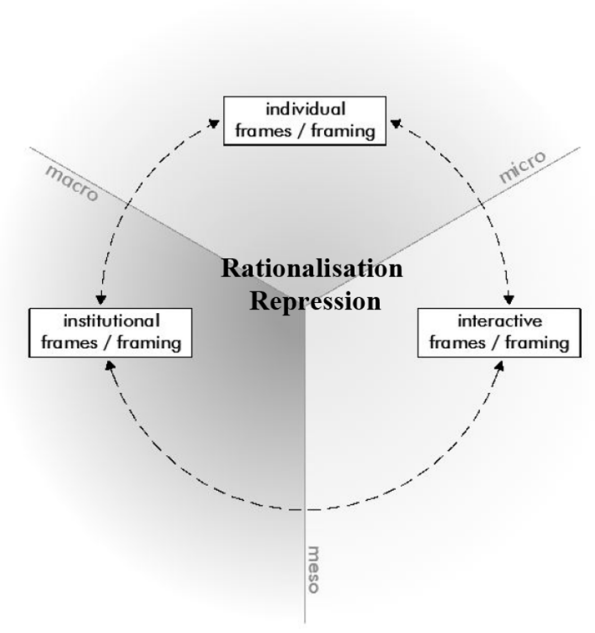

Figure 6.

Source: (own illustration) 
IJCHM

34,2

stakeholder groups collectively and individually distanced themselves from the media stance, "embracing the multifaceted nature of seasonal employment." Instead, they provided inductive rationales (Lounsbury and Glynn, 2001) based on their work experiences, interests and knowledge. Given the continuous engagement with seasonal work, stakeholders may internalize this component of employment to the extent that it transforms into a taken-for-granted reality. Y1ldirım (2021) argues that employees can internalize these problems as a normal, natural part of their job, creating a frail, superficial consent. However, the employment experiences of seasonal workers may undermine this consent. For example, Ainsworth and Purss (2009) found a strong contrast between employers' expectations during recruitment and the reality of their work, where seasonal workers were treated "as a cost and commodity" (230). Similarly, Guillaume et al. (2019) showed that seasonal workers experienced less job quality than standard workers. Nevertheless, sociocultural factors such as the relevance of a "sense of community" (McCole, 2015) for seasonal workers can contribute to more satisfying, sustainable employment and a more positive employment image.

The repression of pessimism also supports attenuation and becomes apparent in the framing of HR problems. On the one hand, the media were "emphasizing the decrease in attraction and loyalty from (potential) employees." This shows that the HR work of an organization influences the construction of TEI. The managers in our study were "refusing (to discuss) employment-related difficulties" in peer conversations and were "downplaying personnel facts and figures" in the interviews, confirming that they are often unaware of recruitment and retention problems (Baum, 2018, p. 727). Paradoxically, the managers still created intersubjective meanings even though they deliberately witheld first-hand knowledge. Consequently, common ground among managers may also emerge through alienation and passiveness. Importantly, the managers did not build common ground regarding HR problems. Rather, they established taboo zones, which prevented the emergence of substantial common ground, stabilizing the common image of poor employment practices. To attract the next generation of tourism employees (Goh and Okumus, 2020), employers must tackle structural HR problems. Attenuation in the context of HR problems gives rise to serious concerns in the construction of tourism employment because it prevents employers and managers from seeing, understanding and changing the management of people in tourism. It precludes the evaluation of many constructive suggestions for fostering more sustainable employment, careers and working practices (Baum, 2019a; Solnet et al., 2015; Chang and Busser, 2020), which could also improve TEI.

\section{Conclusions and implications}

\subsection{Conclusions}

This study found that radicalization in the construction of TEI leads to polarized positions, intense rivalry between employers and employees and the reduction of tourism employment questions to problematic issues or the refusal to acknowledge structural employment problems. By contrast, attenuation produces problematic, taken-for-granted assumptions about important facets of tourism employment, thus creating indifference and undermining a constructive discourse on the central aspects of tourism work.

\subsection{Theoretical implications}

This study supports the general use of frame analysis in tourism and hospitality research (Leung et al., 2019), broadening the scope of its application to TEI. Frame analysis is highly useful for exploring the processes and dynamics that create TEI. This approach goes beyond studying the role of individual perceptions about specific features of tourism work, such as bad management behavior (Hight et al., 2019) and the widely accepted, nearly 
objective employment structures such as limited career opportunities (Goh and Okumus, 2020). Instead, it focuses on the interplay of the individual, interactive and institutional frames/framing of different aspects of TEI, concentrating on the dynamics that characterize these processes and the problematic sociocultural and political constellations these dynamics create for tourism employment.

The research has not examined the dynamics that pervade the construction of TEI. We have conceptualized the main dynamics across all analysis levels as radicalization and attenuation. Radicalization sharpens language, cognition and culture, leading to a "contraction of meaning" that stabilizes and reinforces restricted frames to the "exclusion of alternative interpretations" (Cornelissen et al., 2014, p. 699). Radicalization intensifies a destructive, dysfunctional thrust of ideological and emotional antagonism that negatively affects tourism stakeholders' capacity to find productive compromises. By contrast, attenuation supports the development, preservation and extension of superficial forms of language, cognition and culture. This results in vague and frail meaning constructs that manifest as false issues or nonissues (Ansari et al., 2013), which hinder fundamental alignments of tourism employment.

\subsection{Practical implications}

The poor, one-sided image of employment in tourism industries is not driven exclusively by major employment issues but is also based on the dynamics that lead to these image constructions. Thus, gaining a deeper knowledge of these processes is important for tourism employment practices. The two cross-level dynamics of "radicalization" and "attenuation" make these processes both conflict-driven and destructive, as well as indifferent and superficial. Therefore, breaking through and changing these dynamics is an important step toward improving and consolidating TEI.

First, more pragmatism is required in the framing of tourism employment and work. Pragmatism from all stakeholders, including a more balanced media information policy, should aim to de-emotionalize and de-escalate image construction processes, allowing "the obvious contrast of glamour" and "low menial status" (Riley et al., 2002, p. 23) to be set aside. Pragmatism stresses the variety of work in tourism while exploring the potential for attractive jobs and decent working conditions within the industry. A more problem-oriented, rational framing of tourism employment could create more sustainable employment relations, a more productive and humane working environment, and thus an attractive employment image.

Moreover, the framing of tourism employment must be transformed based on open discussions and a critical review of the industry workplace (Baum, 2019a, 2019b), including all aspects that are negative or positive, appealing or repellent, obvious or hidden. To strengthen innovative approaches, younger generations of stakeholders who stand for progressive ideas should be involved in these discussions. This could lead to a more differentiated understanding, overcome rationalization and repression and help tourism stakeholders to jointly transform tourism employment.

Tackling radicalization and attenuation in the construction of TEI calls for a "new deal" between tourism stakeholders. This should aim to end "information warfare" while inaugurating a new era of tourism employment by fulfilling both the legitimate interests of employees (e.g. decent social standards of work) and employers (e.g. flexible working hours). Government institutions, particularly at the regional level, should actively support this new deal by, for example, offering sustainable childcare infrastructure or public transport, including in remote locations. The powerful divergent interests and economic and social pressures in this industry make this a complex task. However, given the massive economic (e.g. labor scarcity) and social (e.g. precarious work) problems of tourism employment, 
IJCHM

34,2

which were exacerbated by the COVID-19 pandemic (Baum et al., 2020), changing how employment images are constructed is crucial for the success of tourism industries.

\subsection{Limitations and future research}

This study has several limitations. First, we concentrated on employees and managers/ employers as the most relevant stakeholders. However, other stakeholders may also have considerable influence on the construction of TEI. For example, local residents could be of special interest for future studies in this field. Second, at the meso-level, we analyzed data collected in the specific context of arranged get-togethers. More spontaneous encounters could generate more authentic data. Third, at the macro-level, we were limited to input, such as media reports and comments over a specific period, which confined us to cultural conventions that garnered media attention. Finally, since the empirical part of this study was conducted prior to 2020, it is important to study how the COVID-19 pandemic has influenced the cross-level dynamics of radicalization and attenuation in the construction of TEI.

\section{Notes}

1. The data analysis was carried out in German and the empirical examples were translated into English for the material's disclosure (interviews and media products were translated nonliterally and conversations were largely translated literally).

2. We distinguished between working conditions and payment because, in the interviews, peer conversations and media, payment was separated from other working conditions, particularly regarding long and flexible working hours and physical and psychological workloads.

\section{References}

Ainsworth, S. and Purss, A. (2009), "Same time, next year? Human resource management and seasonal workers", Personnel Review, Vol. 38 No. 3, pp. 217-235.

Altheide, D.L. and Schneider, C.J. (2013), Qualitative Media Analysis, Sage, Thousand Oaks, CA.

Ansari, S.M., Wien, F.H. and Gray, B. (2013), "Constructing a climate change logic: an institutional perspective on the "tragedy of the commons", Organization Science, Vol. 24 No. 4, pp. 1014-1040.

Armstrong, R. (2017), "Modern slavery: risks for the UK hospitality industry", Prog. Resp. Tour, Vol. 67.

Austrian Hotelier Association (2021), "Deloitte und ÖHV-Tourismusbarometer 2020”, available at: www.oehv.at/themen-recht/studien-fakten/deloitte-und-oehv-tourismusbarometer2020/und_ÖHV-Tourismusbarometer_2020_(oehv.at) (accessed 5 September 2021).

Baum, T. (2018), "Sustainable human resource management as a driver in tourism policy and planning: a serious sin of omission?", Journal of Sustainable Tourism, Vol. 26 No. 6, pp. 873-889.

Baum, T. (2019a), "Hospitality employment 2033: a back casting perspective", International Journal of Hospitality Management, Vol. 76, pp. 45-52.

Baum, T. (2019b), "Does the hospitality industry need or deserve talent?", International Journal of Contemporary Hospitality Management, Vol. 31 No. 10, pp. 3823-3837.

Baum, T., Mooney, S.K., Robinson, R.N. and Solnet, D. (2020), "COVID-19's impact on the hospitality workforce - new crisis or amplification of the norm?", International Journal of Contemporary Hospitality Management, Vol. 32 No. 9, pp. 2813-2829.

Benford, R.D. and Snow, D.A. (2000), "Framing processes and social movements: an overview and assessment”, Annual Review of Sociology, Vol. 26 No. 1, pp. 611-639. 
Benner, M.J. and Tripsas, M. (2012), "The influence of prior industry affiliation on framing in nascent industries: the evolution of digital cameras", Strategic Management Journal, Vol. 33 No. 3, pp. 277-302.

Biehl, K. and Kaske, R. (Eds) (2011), Tourismus in Österreich 2011 Mit Einer Sonderauswertung Des Österreichischen Arbeitsklimaindex, Kammer für Arbeiter und Angestellte für Wien, Vienna.

Brown, E., Arendt, S. and Bosselman, R. (2014), "Hospitality graduates' perceptions of career factor importance and career factor experience", International Journal of Hospitality Management, Vol. 37 No. February, pp. 58-67.

Cameron, L., Miller, P. and Frew, E. (2009), "Relationship marketing in the recruitment and retention of service industry staff in family-owned businesses", Journal of Human Resources in Hospitality and Tourism, Vol. 9 No. 1, pp. 71-91.

Casado-Díaz, J.M. and Hipólito, S. (2016), "Wage differences in the hospitality sector", Tourism Management, Vol. 52, pp. 96-109.

Chang, W. and Busser, J.A. (2020), "Hospitality career retention: the role of contextual factors and thriving at work", International Journal of Contemporary Hospitality Management, Vol. 32 No. 1, pp. 193-211.

Cornelissen, J.P. and Werner, M.D. (2014), "Putting framing in perspective: a review of framing and frame analysis across the management and organizational literature", Academy of Management Annals, Vol. 8 No. 1, pp. 181-235.

Cornelissen, J.P., Mantere, S. and Vaara, E. (2014), "The contraction of meaning: the combined effect of communication, emotions and materiality on sensemaking in the stockwell shooting", Journal of Management Studies, Vol. 51 No. 5, pp. 699-736.

Czarniawska, B. (2004), Narratives in Social Science Research, Sage, London.

Daniel, A.D., Costa, R.A., Pita, M. and Costa, C. (2017), "Tourism education: what about entrepreneurial skills?", Journal of Hospitality and Tourism Management, Vol. 30, pp. 65-72.

Entman, R.M. (1993), "Framing: towards clarification of a fractured paradigm", Journal of Communication, Vol. 43 No. 4, pp. 51-58.

Fes, N. (2018), "Europe dealing with shortages of travel and hotel personnel", Tourism Review News, available at: www.tourism-review.com (accessed 13 August 2019).

Gehrels, S. (2019), Employer Branding for the Hospitality and Tourism Industry: finding and Keeping Talent, Emerald, Bingley.

Goh, E. and Lee, C. (2018), "A workforce to be reckoned with: the emerging pivotal generation Z hospitality workforce”, International Journal of Hospitality Management, Vol. 73, pp. 20-28.

Goh, E. and Okumus, F. (2020), "Avoiding the hospitality workforce bubble: strategies to attract and retain generation $Z$ talent in the hospitality workforce", Tourism Management Perspectives, Vol. 33, p. 100603.

Goh, E. and Baum, T. (2021), "Job perceptions of generation $Z$ hotel employees towards working in COVID-19 quarantine hotels: the role of meaningful work", International Journal of Contemporary Hospitality Management, Vol. 33 No. 5, pp. 1688-1710.

Guillaume, P., Sullivan, S.E., Wolff, H.G. and Forret, M. (2019), "Are there major differences in the attitudes and service quality of standard and seasonal employees? An empirical examination and implications for practice", Human Resource Management, Vol. 58 No. 1, pp. $45-56$.

Hight, S.K., Gajjar, T. and Okumus, F. (2019), "Managers from 'hell' in the hospitality industry: how do hospitality employees profile bad managers?", International Journal of Hospitality Management, Vol. 77, pp. 97-107.

Janta, H., Lugosi, P., Brown, L. and Ladkin, A. (2012), "Migrant networks, language learning and tourism employment", Tourism Management, Vol. 33 No. 2, pp. 431-439. 
IJCHM

34,2

Kusluvan, S. (2003), Managing Employee Attitudes and Behaviors in the Tourism and Hospitality Industry, Nova Publishers, New York, NY.

Kusluvan, S. and Kusluvan, Z. (2000), "Perceptions and attitudes of undergraduate tourism students towards working in the tourism industry in Turkey", Tourism Management, Vol. 21 No. 3, pp. 251-269.

Kusluvan, S., Kusluvan, Z., Ilhan, I. and Buyruk, L. (2010), "The human dimension: a review of human resources management issues in the tourism and hospitality industry", Cornell Hospitality Quarterly, Vol. 51 No. 2, pp. 171-214.

Ladkin, A. (2011), "Exploring tourism labor”, Annals of Tourism Research, Vol. 38 No. 3, pp. 1135-1155.

Lee, L. and Madera, J.M. (2019), "A systematic literature review of emotional labor research from the hospitality and tourism literature", International Journal of Contemporary Hospitality Management, Vol. 31 No. 7, pp. 2808-2826.

Lefsrud, L.M. and Meyer, R.E. (2012), "Science or science fiction? Professionals' discursive construction of climate change”, Organization Studies, Vol. 33 No. 11, pp. 1477-1506.

Leung, X.Y., Xue, L. and Wen, H. (2019), "Framing the sharing economy: toward a sustainable ecosystem”, Tourism Management, Vol. 71, pp. 44-53.

Lounsbury, M. and Glynn, M.A. (2001), "Cultural entrepreneurship: stories, legitimacy and the acquisition of resources", Strategic Management Journal, Vol. 22 Nos 6/7, pp. 545-564.

McCole, D. (2015), "Seasonal employees: the link between sense of community and retention", Journal of Travel Research, Vol. 54 No. 2, pp. 193-205.

McGinley, S.P., Hanks, L. and Line, N.D. (2017), "Constraints to attracting new hotel workers: a study on industrial recruitment", International Journal of Hospitality Management, Vol. 60, pp. 114-122.

McGinley, S.P., Yang, W. and Zhang, L. (2018), "Snob appeal? Impact of company status perceptions on employee recruitment", Journal of Hospitality Marketing and Management, Vol. 27 No. 1, pp. 85-105.

McPhail, R., Patiar, A., Herington, C., Creed, P. and Davidson, M. (2015), "Development and initial validation of a hospitality employees' job satisfaction index", International Journal of Contemporary Hospitality Management, Vol. 27 No. 8, pp. 1814-1838.

Mayring, P. (2014), "Qualitative content analysis: theoretical foundation, basic procedures and software solution”, available at: https://nbn-resolving.org/urn:nbn:de:0168-ssoar-395173 (accessed 2 September 2021).

Mooney, S.K., Harris, C. and Ryan, I. (2016), "Long hospitality careers - a contradiction in terms?”, International Journal of Contemporary Hospitality Management, Vol. 28 No. 11, pp. 2589-2608.

Murray, D.W. and Ayoun, B.M. (2010), "Hospitality student perceptions on the use of sustainable business practices as a means of signaling attractiveness and attracting future employees", Journal of Human Resources in Hospitality and Tourism, Vol. 10 No. 1, pp. 60-79.

Oliver, P. and Johnston, H. (2000), "What a good idea! Frames and ideologies in social movement research", Mobilization, Vol. 5, pp. 1-18.

Richardson, S. (2009), "Undergraduates' perceptions of tourism and hospitality as a career choice", International Journal of Hospitality Management, Vol. 28 No. 3, pp. 382-388.

Richardson, S. (2010), "Generation Y's perceptions and attitudes towards a career in tourism and hospitality”, Journal of Human Resources in Hospitality and Tourism, Vol. 9 No. 2, pp. 179-199.

Riley, M., Ladkin, A. and Szivas, E. (2002), Tourism Employment: Analysis and Planning, Channel View, Clevedon.

Robinson, R.N., Martins, A., Solnet, D. and Baum, T. (2019), "Sustaining precarity: critically examining tourism and employment", Journal of Sustainable Tourism, Vol. 27 No. 7, pp. 1008-1025. 
Sacks, H., Schegloff, E. and Jefferson, G. (1974), "A simplest systematics for the organization of turntaking in conversation”, Language, Vol. 50 No. 4, pp. 696-735.

Schneider, A. and Treisch, C. (2019), "Employees' evaluative repertoires of tourism and hospitality jobs", International Journal of Contemporary Hospitality Management, pp. 3173-3191.

Snow, D. and Byrd, S. (2007), "Ideology, framing processes and Islamic terrorist movements", Mobilization: An International Quarterly: June 2007, Vol. 12 No. 2, pp. 119-136.

Solnet, D. and Hood, A. (2008), "Generation Y as hospitality employees: framing a research agenda", Journal of Hospitality and Tourism Management, Vol. 15 No. 1, pp. 59-68.

Solnet, D., Kralj, A. and Baum, T. (2015), "360 Degrees of pressure: the changing role of the HR professional in the hospitality industry", Journal of Hospitality and Tourism Research, Vol. 39 No. 2, pp. 271-292.

Tsaur, S.H. and Yen, C.H. (2018), "Work-leisure conflict and its consequences: do generational differences matter?", Tourism Management, Vol. 69, pp. 121-131.

Tyrol Chamber of Labour (2020), Der Tiroler Arbeitsmarkt, Arbeiterkammer Tirol, Innsbruck.

Wan, Y.K.P., Wong, I.A. and Kong, W.H. (2014), "Student career prospect and industry commitment: the roles of industry attitude, perceived social status and salary expectations", Tourism Management, Vol. 40, pp. 1-14.

Westby, D.L. (2004), "Strategic imperative, ideology and frames", in Hank, J. and Noakes John, A. (Eds), Frames of Protest: Social Movements and the Framing Perspective, Rowman \& Littlefield Publishers, Lanham, MD, pp. 217-235.

Winkielman, P., Knutson, B., Paulus, M. and Trujillo, J. (2007), "Affective influence on judgments and decisions: moving towards core mechanisms", Review of General Psychology, Vol. 11 No. 2, pp. 179-192.

Ylldırım, M. (2021), "Tracing the consent, adaptation and resistance practices of an 'unsustainable' workforce: the governmentality of workplaces in tourism industry", Tourism Management, Vol. 84, p. 104260.

Zopiatis, A. (2007), "Hospitality internships in Cyprus: a genuine academic experience or a continuing frustration?", International Journal of Contemporary Hospitality Management, Vol. 19 No. 1, pp. 65-77.

Zopiatis, A., Krambia-Kapardis, M. and Varnavas, A. (2012), "Y-ERS, X-ERS and boomers: investigating the multigenerational (MIS) perceptions in the hospitality workplace", Tourism and Hospitality Research, Vol. 12 No. 2, pp. 101-121.

\section{Corresponding author}

Mike Peters can be contacted at: mike.peters@uibk.ac.at

For instructions on how to order reprints of this article, please visit our website: 